\title{
Comparative and Historical Aspect of Yakut Vocabulary of Common Names of Animal Body Parts
}

\author{
Ninel V. Malysheva, Alla E. Bozhedonova \\ and Alina P. Vasilyeva* \\ M. K. Ammosov North-Eastern Federal University \\ 58 Belinsky Str., Yakutsk, 677000, Russia
}

Received 02.11.2018, received in revised form 18.12.2018, accepted 25.12.2018

The historical stage of the development of the Turkic languages, their interconnection with the languages of the Mongolian and Tungusic group and with other unrelated languages, the history of the migration of the Turkic peoples and their language contacts with other peoples and tribes are still of great scientific interest for ethnographers, historians, and for linguists. The vocabulary of common names of the animal world in the Turkic languages is represented by one of the most interesting vocabulary strata, characterised by the antiquity, variety and unique identity of lexical units. In this article the common names of parts of the animal's body are analyzed within the framework of three lexical and semantic groups: 1. External structure, including 1.1) Head, neck; 1.2) Corpus; 1.3) Limbs (outgrowths) and their types; 1.4) Skin coverings and their types; 2. Internal structure; 3. Internal parts of a body and their types. The lexical, semantic and phonostructural features of the 12 Yakut stems have lexical parallels in other Turkic languages, as well as their semantic transitions. The article describes the attempt to determine the relation of the Yakut language to other modern Turkic languages, as well as the change in the lexical meanings of the examined stems from the Proto-Turkic form to the modern ones. As a result, it has been established that the material of the Yakut language is of decisive importance for the Proto-Turkic reconstruction in terms of many parameters.

Keywords: zoological vocabulary, modern Turkic languages, Proto-Turkic form, lexical parallels, phonostructure, phonological singularity, lexical and semantic features, history of language.

The study was carried out within the research project "Heroic epics of the Turkic-Mongolian peoples of Eurasia: problems and prospects for comparative study".

Research area: culturology.

Citation: Malysheva, N.V., Bozhedonova, A.E., Vasilyeva, A.P. (2018). Comparative and historical aspect of Yakut vocabulary of common names of animal body parts. J. Sib. Fed. Univ. Humanit. soc. sci., 12(7), 1163-1173. DOI: 10.17516/1997-1370-0357.

(C) Siberian Federal University. All rights reserved

* Corresponding author E-mail address: ninel_malysheva@mail.ru; bozhedonova2015@mail.ru; sunny_girl_a@mail.ru This work is licensed under a Creative Commons Attribution-NonCommercial 4.0 International License (CC BY-NC 4.0). 


\section{Introduction}

The origin and historical development of the Yakut language are significantly different from those ones of the most modern Turkic languages. Its early isolation from the Turkic languages and certain influence from related and unrelated languages led to the formation of a peculiar grammatical structure and an unusual lexical composition (Stralenberg, 1730, Betlingk, 1851, Vamberi, 1885, Malov, 1941, Kaluzhinskii, 1959, Ubriatova, 1960 Petrov, 1997, Shirobokova, 2005, Levin, 2013, etc.) The unusual nature of the lexical composition of the Yakut language can be explained by the presence of lexemes of unknown origin, as well as a remarkably big strata of Mongolian and Tungusic borrowings. According to E. I. Ubriatova, "the uniqueness of the Yakut language has always required the comparison of each of its details with analogous material of other Turkic languages" (Ubryatova, 1960: 1). A lot of scientific works have been devoted to the study of the relations of the Yakut language with modern Turkic, Mongolian and Tungusic languages. Historical phonetics, morphology, vocabulary of the Yakut language are examined in comparison with the Turkish, Altaic, Khakass, Tuvan, Shor, Mongolian, Evenki, Buryat, Kyrgyz and other languages. Currently, the vocabulary, phonetics, orthoepia, dialectology and grammar of the Yakut language are studied quite extensively and diversely. The publication of the latest volumes of the "The Large Dictionary of the Yakut language" (LDYL) is being completed now. The dictionary will serve as the basis for lexicographical research and will become an impetus for the development of the historical vocabulary of the Yakut language. Zoological vocabulary in the Yakut language is represented by one of the insufficiently studied objects of research and at the same time the most interesting strata of the vocabulary, which is characterised by antiquity, polysemy and the identity of lexical units. The vocabulary of the common names of animal world in the Turkic languages contains historical information that is closely connected with the thinking, ethnography and specific ethnic mentality (worldview) of the Turkic people, whose main occupations have been animal husbandry and hunting since ancient times. In this regard, a comparative study of the Yakut vocabulary of the common names of animal body parts seems an urgent task.

The scientific novelty of the study is that the common names of animal body parts are for the first time ever considered as a separate lexical and semantic group in contrast to similar forms from other Turkic languages, including the languages of the ancient Turkic literary texts and the Proto-Turkic forms. Also, one of the key points of the novelty of the research is focusing on the issue of the relationship of the Yakut language to other modern Turkic languages in a comparative aspect. 


\section{Research methods and methodology}

The methodological base of research in the field of comparative phonetics, vocabulary and grammar of the Turkic languages is prominent works of Russian and foreign scientists: O. N. Böhtlingk， V. V. Radlov， A. N. Samoilovich， S. E. Malov, N. A. Baskakov, E. V. Sevortwan, B. A. Serebrennikov, A. M. Shcherbak, N. Z. Gadzhieva, A. T. Kaidarov, G. S. Sadvakasov,A. V. Dybo, A. G. Shaikhulov, N. N. Shirobokova, G. G. Levin, etc. In the field of historical phonetics, vocabulary and grammar of the Yakut language the leading researchers are: L. N. Kharitonov, E. I. Ubriatova, N. K. Antonov， N. D. Diachkovskii， E. I. Korkina， P. A. Sleptsov， M. S. Voronkin, N. E. Petrov, S. A. Ivanov, G. G. Filippov, N. N. Efremov, N. I. Danilova, S. D. Eginova, I. N. Novgorodov et. al. The research method of the analysis is the comparative one that helps to discover lexical parallels, to reveal the general and specific traits (lexicalsemantic and structural features) in the languages in question.

Distributive analysis made it possible to find out various phonostructural features of lexical parallels using the following three parameters: a) absolute coincidence (for example, $[\mathrm{CVC}]=[\mathrm{CVC}]$ ); b) partial coincidence (for example, $[\mathrm{CVC}] \rightarrow[\mathrm{CV}$ : $\mathrm{C}]$ ); c) coincidence subjected to structural changes (for example, [CVC] $\rightarrow[\mathrm{VCC}]$ ). One of the methodological foundations of the work is the cognitive and ideographic method developed by A. G. Shaikhulov and put forward in due time by the German scientist-lexicographers Rudolf Hallig and Volter Vartburg, whose views are now getting more and more supporters. This method allows researchers to compose lexical and semantic groups with the inner subgroups and to build a fairly universal and harmonious system for the cognitive classification of nominal stems. The system proposed for describing lexical stems within the ideographic groups contributes to a fairly strict identification and definition of a vocabulary stratum specific for each Turkic language. This system enables scientists to make a typological comparison at the level of semantic stems, helps to elucidate the ethnolinguistic features of the objective world reflected by lexical structure (Shaikhulov, 2000). The analysis is also grounded on the methodological idea of G. G. Levin. According to G. G. Levin, the ancient lexical stratum, as well as the nature of kinship and a close relationship between languages, can be studied by identifying the stability and variability of the phonostructural, structural and semantic stems. Due to the fact that the work is devoted to determining the relationship of the Yakut language with the Uyghur and Old Uyghur languages, it would be nothing but appropriate to rely on the methodological idea of G. G. Levin. 


\section{Vocabulary of common names of animal body parts}

In Russian and foreign Turkology of recent years, lexicological studies have been markedly brought to the forefront: many research centers in the Turkic languages speaking republics, neighboring countries and far abroad compile ideographic dictionaries; study lexical-thematic, lexical-semantic groups of words; create regional dictionaries and dialectal vocabularies. As we know, the basis for developing the materials of any lexicological research lies in the classification of paradigms. At the first stage, there is a general identification of the broadest thematic groups, which gradually narrow down to smaller subgroups: "The identification and development of multidimensional lexicalsemantic word groups (microfields) is very important in terms of methodology in the process of laying the foundation for lexicological research" (Shaikhulov, 2000).

In this connection, 12 stems, identified by the methodology of A. G. Shaikhulov, are analyzed within the following lexical-semantic groups: "External structure: head, neck” (2): Yakut - muos (1. horns; 2. made of horn, bone; 3. ivory; fossil ivory) (LDYL, 2009), Yakut - tumus (1. beak; 2. forward front of the head of some animals, snout) (LDYL, 2014); "External structure: limbs (outgrowths) and their types" (9): Yakut - tujaq (1. hoof; 2. part of the animal's leg from the knee to the hoof, calf (used to make the kholodets - jellied meat or fish)) (LDYL, 2014), Yakut — kuturuk (1. tail (of animals and birds); 2. fig. spur of the mountain, slides, tapering edge of the island, lakes, etc.) (LDYL, 2007), Yakut — iiraaq (1. split, splitting (at the hoof); 2. the interval between two parts in connection; spacing between the fingers and toes, between the hoofs of cattle and between the branches of a tree; 3. a cloven hoof) (Pek., 1959), Yakut - silin (udder) (Pek., II volume, 2219), II sirin (udder) (LDYL, 2011), Yakut — kïnat (1. wing, wings) (LDYL, 2008); "Skin coverings and their types": Yakut — tü: (1. animal wool; thin feathers of birds, down; 2. coat; 3. flok) (Pek., 1959); Yakut - suy (animal hair, wave (horse or cow); faded cattle hair) (Pek., 1959), (wool from animals which shed) (LDYL, 2012); sa: I (1. fat deposits on the horse's withers; 2. withers) (LDYL, 2011), Yakut — siäl (mane) (Pek., 1959; LDYL, 2011); “Internal parts of a body and their types" (1): Yakut — moroq (double chin) (LDYL, 2009).

It should be noted that the Yakut word muos has a reliable Altaic etymology: Mongolian - mörer-sun (cartilage) (Comparative Grammar of Turkic Languages. Lexics, hereinafter referred to as CGTLL, 2001), tungus muni (tendon) (CGTLL, 2001), Kor. miïinim (fangs) (Starostin, 1991). Unlike other languages belonging to the Altaic language family, there is another meaning of the represented token muos (ivory; fossil ivory) and (made of horn, bone) in the Yakut language. 
In all found sources the stem tujaq means a hoof, except for the Chagatai language, where it means claws, nails. This phenomenon can be called a semantic transition within a single lexical-thematic group. In all Turkic languages the token kuturuk means tail. In the Yakut language and in the language of Mahmud Kashgari's masterpiece "Diwan Lughat al-Turk" (Compendium of the languages of the Turks) there is a figurative meaning of the represented stem (back side, back, end of something, some action). In addition, the Yakut stem kuturuk also has other figurative meanings: a spur of a mountain or an offshoot, a tapering edge of an island, a lake, etc.; aft (e. g. of a ship, a boat); trans. henchmen and protectors of someone, sycophants, lap-dogs. This lexical stem also has some analogy in the Tungusic qujrguj (CGTLL, 2001) and Mongolian languages: Mongol kudurga (caudal strap) (CGTLL, 2001): Middle Mongol ḥudurḥa (CGTLL, 2001), written Mongol qudurga (CGTLL, 2001), Khalkha Mongol qudraga (CGTLL, 2001), Buryat qudarga (SIGTYAL, 2001). The Altai prototype of the lexeme is represented as follows: k'udur-g (tail) (CGTLL, 2001). The first meaning of the Yakut iiraaq in the Turkic languages is "the hoof of cloven-hoofed animal". In the Yakut language the second meaning of this reflex means "the interval between two parts in connection; the spaces between the fingers and toes, between the hoofs of the cattle and between the branches of the tree". The second meaning in the Yakut language is used more often than the first in the colloquial language. In all the Turkic languages under consideration, the stem silin (udder) has a stable preservation of lexical meaning. Lexical parallels are also traced in the Mongolian deley (udder) and the Tungus dilina (udder).

In most languages, the stem kïnat means a wing, except for the Turkish, Nogai, Altai, Khakass and Chuvash languages, in which lexical parallels have such meaning as 'a fin'. This phenomenon can be explained as a semantic transition in the object function. As for the stem tü: in all the considered examples the main meaning of lexical parallels is "hair on the human body, wool, fluff". The original meaning, apparently, is "hair on the body", including undercoat of animals (CGTLL, 2001). In addition, the Yakut reflex also means "processed fur, wool, down of animals and birds; coll. down, fluff (plants); sewn from wool, woolen, downy; made of down, feathers". In the language of "Diwan Lughat al-Turk", in addition to the meaning "hair on the body, wool, feathers", there is also the second meaning - "color, coloration, horse coat color". The Yakut form sun is regarded as closer to the following forms - Proto-Turkic, ancient Uyghur, Karakhanid Uyghur, Uyghur, Turkic, Azerbaijani, Turkmen, Kumyk, Tatar, Uzbek languages. Stability of the lexical meaning of the Yakut stem suy (animal wool) is observed in most of the Turkic languages in question, except for the Altai, in which the reflex stands for 
"feather". This phenomenon can be attributed to a semantic transition within one lexicalthematic group, i. e. within the system of common animal names. Lexical unit sa: $\mathbf{I}$ in languages of medieval books "Diwan Lughat al-Turk" and "Kutadgu Bilig", as well as in the Turkmen, Karachay-Balkar, Kumyk, Nogai, Altai, in southeastern languages means "withers, a place where mane grows"; in the Chagatai, Kazakh, Karakalpak, Kyrgyz, Tuvan languages - "fat under the mane"; in the Chagatai, Shor, Tofalar, Chuvash, Old Osman, southwestern, northwestern, southeastern languages - the meaning is "mane". In the Kazakh, Azerbaijani and Yakut languages there is a metaphorical meaning in the form of "mountain range, pass". The following stems have the same meaning: Yakut siäl (1. mane; 2. sort of long grass growing on hillocks) // old Turkic — jel (mane of a horse), Karakhanid Uyghur - je: I (mane of a horse), Turkic - yele (mane of a horse), Turk. dial. yeli (mane of a horse), Sar. Uyghur — jelä (mane of a horse), Khakass čilin (mane of a horse), Tuvan čel (mane of a horse). In the Yakut language there is a second meaning, which is "a sort of long grass growing on hillocks". Both meanings are actively used in the Yakut language.

In all sources, except for the Yakut, Turkish, Azerbaijani and Turkmen languages reflex moroq means a goiter. In the Yakut language, the word moroq is represented as a "double chin". Perhaps this is due to the physiological sign of lexical reflexes, because at the place of the goiter the so-called "second chin" appears, therefore, it is assumed that the Yakut form has such an implication.

In contrast to other Turkic languages, the following phonetic phenomena are observed in Yakut stems: the formation of a diphthong in the Yakut word with the omission of the following inlaut consonants: (y): Yakut — muos — Kar. Uyghur mü̈üz, Sal. - mojus, Sar. Uyghur - mogus, Turk., Az., Kar. - mü̈üz; (j):): Yakut - muos - Tuv. - myjys, Karakalp. - müjüz, Nog., Kaz. - müjiz, Kyrgyz — müjüz; (jn): Yakut — muos — Gag. — bojnuz, Turk. — bujnuz; (jy): Yakut - muos - Proto-Turkic — bujnuz; (ng): Yakut - muos - Uyghur müngüz; (g): Yakut — muos - Tat. — mügĭz, Bash. — mŭgŭz, Uzb. — muguz; correspondence of the anlaut consonant $(\mathrm{m} \sim \mathrm{b}):$ Yakut - muos $\sim$ Proto-Turkic bujyuz, Gag. - bojnuz, Az., Turk. - bujnuz; correspondence of finite consonant elements $(\mathrm{s} \sim \mathrm{z}):$ Yakut — muos $\sim$ Proto-Turkic — bujnuz, Gag. — bojnuz, Az., Turk. — bujnuz, Uyghur — müngüz, Kar. Uyghur — mü̈üz, Kar. — müyüz, Tat. mŭgĭz, Bash. — mŭgŭ́z, Nog., Karakalp. — müjüz, Kaz. — müjiz, Kyrgyz. — müjüz, Alt. — mü: s, Uzb. - muguz; the correspondence of the Yakut diphthong (uo) to the Altai and Khakass long (ü:): Yakut — muos Khak. — mü: s, Alt. — mü: s; the 
omission of the inlaut consonant: Yakut - tumus - Proto-Turkic - tumšyk, old Uyghur - tumšuq, Kar. Uyghur - tumšuq, Mid. Uyghur - tumšyq, new Uyghur, Mid. Oghuz — domšaq, domšuq, tumšuq, dumšaq, Khorezmian Turkic - tumšuq, Chag. - tumšuq, Turk. - tomskuk, Turkmen - tumšuq, Sal. — tunčux, Tat. tŭmšyq, Bash. - tŭmšŭq, Bash. dial. - tomšoq, Nog. - tumsyq, Karakalp. tumsuq, Kazakh - tŭmšyq, Kyrgyz. - tumšuq, Altai - tumčuq, Kum. dial. of Altai - tunčuq, Uzbek - tunčuq, Uyghur - tumšuq, Lop. dial. - tumšuq, Sar. Uyghur - tymsyq, Khakass - tumzux, Tuvan — dumčuq; the correspondence of the initial consonants $(\mathrm{t} \sim \mathrm{d})$ : Yakut — tujaq $\sim$ Turkic — dujnaq, Tuvan — dujug; the correspondence of the final consonants $(q \sim \gamma)$ : Yakut — tujaq Kar. Uyghur — tujar, Sal. — c'enar, Sar. Uyghur - tujar, tyjyr; the correspondence of the vocalisms in the first syllable $(\mathrm{u} \sim \mathrm{o}$, e): Yakut — tujaq $\sim$ Turk. — tojnaq, Sal. — c'enar; the correspondence of the vocalisms in the second syllable $(\mathrm{a} \sim \mathrm{u})$ : Yakut — tujaq Tuvan - dujug, Sar. Uyghur - tyjyr; omission of the inlaut consonant element (y), (n), (r) in the Yakut: Yakut — tujaq — Proto-Turkic — tujyak, Mid. Uyghur tujnaq, Khorezmian Turkic - tujnaq, Turkish — dujnaq “hoof”, Turkmen — tojnaq "hoof", Altai - tujraq, Khak. - tujrax; correspondence of the anlaut consonant: $(\mathrm{t} \sim \mathrm{d})$ : Yakut — kuturuk Kar. Uyghur — qudruq (DLT), kudruk (QB), Tuv. quduruq; $(\mathrm{t} \sim \mathrm{j}, \mathrm{y})$ : Yakut — kuturuk Uyghur — kujruk, Turk. — gujruk "tail", Tat. — kŭjryk, Turk. — kuyruk; ( $\sim$ z): Yakut — kuturuk $\sim$ Khakass — xuzurux; the correspondence of the auslaut consonant element: $(\mathrm{k} \sim \mathrm{q}, \mathrm{x})$ : Yakut — kuturuk Kar. Uyghur - qudruq, Tuvan - quduruq, Khakass - xuzurux; correspondence of the auslaut consonant element: $(\mathrm{k} \sim \mathrm{q}, \mathrm{x})$ : Yakut — kuturuk $\sim$ Khakass — quzurux, Tuvan - quduruq "tail”; omission of the inlaut vocal (u): Yakut - kuturuk Uyghur — kujruk, Kar. Uyghur — qudruq, kudruk, Turk. — kuyruk, Turkmen — gujruk, Tatar - kŭjryk; the regular correspondence of the unlaut consonant: (s j): Yakut - silin Proto-Turkic: jumur-tka, old Uyghur - jumurra, jumurtra, Turk. - yumurta, Az. - jumurta, Turkm. - jumurtra, Kumyk - jymyrtqa, Tatar - jŭmyrqa, Uzb. dial. - jumurqa; the correspondence of the initial (k) in the Yakut language and (q) of Turkic languages: Yakut — kïnat old Uyghur — qanat, Sal. — qanat, Crimean dial. of Kar. — qanat, Balk, Kum., Tat. — qanat, Tat. dial. qanat, Barab. - qanat, Bashk. — qanat, Nog. — qanat, Karakalp., Kaz. — qanat, Kyrgyz., Alt. — qanat, Alt. dial. — qanat, Uzb., Uyghur, Uyghur dial. — qanat, Sar. Uyghur - qanat, qyjnat, Khakass - xanat; basic correspondence of the Yakut (i) and Turkic (a): Yakut — kïnat old Uyghur — qanat, Sal. — qanat, Crimean dial. 
of Kar. — qanat, Balk, Kum., Tat. — qanat, Tat. dial. — qanat, Barab. — qanat, Bashk. — qanat, Nog. — qanat, Karakalp., Kaz. -qanat, Kyrgyz, Altai — qanat, Alt. dial. — qanat, Uzb., Uyghur, Uyghur dial. — qanat, Sar. Uyghur — qanat, Khakass — xanat, Gag. — kanat, Az. — ganat.

The Yakut stem in relation to the Proto-Turkic form in comparison with other presented here Turkic languages does not have a stable phonological structure of the word, since in all other languages there is a nominal Turkic affix: - rta / rtqa / rra / ra; the correspondence of the anlaut consonant $(\mathrm{t} \sim \mathrm{d})$ : Yakut - tü: $\sim$ Tuvan dük, Tofalar — dük; the correspondence of the long vowels (üü ü): Yakut — tü: Uyghur — tük, Kar. Uyghur — tü, old Uyghur — tü, Mid. Uyghur — tüg, Chag. tük, Khorezmian Turkic — tüg, Mid. Kypch. - tüg, Chag. — tüj, tüg, Turk. — tüj, Gag. — tüj, Az. — tüg, Khal. - ti: k, Turkm. — tüj, Balk. - tük, Kum. - tük, Karakalp. — tük, Kaz. — tük, Kyrgyz — tük, Khak. — tük, Shor. — tük, Tuv. — dük, Tuv. — dük; the correspondence of the long vowels (üï) and (ö) in the northwestern Türkic languages: Yakut — tü: Tat. — tök, Bashk. — tök; the correspondence of the long vowels (üü) in the Yakut and (ě) in the Chuvash languages: Yakut — tü: Chuvash — těk; the correspondence of the long vowels (üü) in the Yakut and long (ii) in the Khalaj languages: Yakut — tü: $\sim$ Khalaj — ti: $\mathbf{k}$; the correspondence of the initial consonants: $(s \sim \mathrm{j})$ : Yakut — suy $\sim$ Proto-Turkic — juy, old Uyghur — juy, Kar. Uyghur — juy, Turkish — jüy, Az. — juy, Turkmen — jüy, Kumyk — jün, Tatar jŭn, Bashk. — jön, Uzbek — juy; the correspondence of the Yakut initial (s) with the Kyrgyz initial (丂̌): Yakut — suy Kyrgyz; the correspondence of the Yakut initial (s) with the Khakass initial (n): Yakut — suy $\sim$ Khakass — nüy; the correspondence of the final Yakut (y) with the final (n) in the northwestern Turkic languages and in the Kyrgyz language: Yakut — suy Kumyk — jün, Tatar — jŭn, Bashk. — jön, Kaz. — źün, Kyrgyz. - žün; the correspondence of the Yakut inlaut vocalism (u) with the inlaut consonant (ü) in some Turkic languages: Yakut — suy Turkish — jüj, Turkmen jü̈, Kumyk — jün, Kazakh — źün, Kyrgyz — žün, Khakass — nüy, Tuvan — čüu; the regular correspondence of the anlaut consonant: $(\mathrm{s} \sim \mathrm{j})$ : Yakut — sa: $\mathbf{I} \sim$ Proto-Turkic ja: I, Kar. Uyghur — ja: l, jal, Chagatai — jal, jaly, old Osm. — jal, jaly, Az. — jal, Khal. — ja: 1, Turkm. — ja: l, Kar. — jal, Kumyk — jal, Tatar — jal, Bashk. — jal, Nogai — jal, Uzbek — jal, Uyghur — jal; the regular correspondence of the anlaut

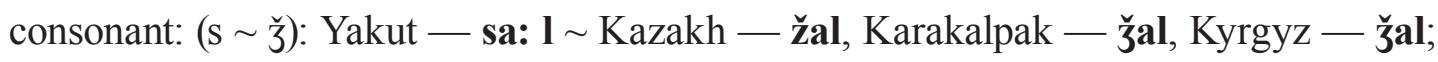
the regular correspondence of the anlaut consonant: $(\mathbf{s} \sim \breve{c})$ : Yakut — sa: I $\sim$ Shor — čal, Tuvan — čal, Tofalar — čal; natural correspondence of the Yakut long (a:) with the short 
vowel (a) in other Turkic languages: Yakut — sa: I new Uyghur — jal, Mid.-Kypch. — jaly, Chagatai — jal, jaly, old Osman — jal, jaly, Turkm. dial. — yal, Az. — jal, Kar. — jal, Karachay Balkar — žal, క̌alga, Kumyk — jal, Tatar — jal, Bashk. — jal, Nog. — jal, Kazakh — žal, Karakalpak — క̌al, Kyrgyz — క̌al, Altai — d'al, Uzbek — jal, Uyghur — jal, Shor — čal, Tuvan — čal, Tofalar — čal; the correspondence of the initial consonant (m) with the initial consonant (b) in other Turkic languages: Yakut moroq Proto-Turkic — bok-agu, Kar. Uyghur — boqaq, Turkish — boğak, Az. buxag, Turkmen — buqaw, Kumyk — buraq, Bashk. — bŭraq, Kazakh — bŭraq, Kyrgyz — boroq, Altai — bogoq, Uzbek — buqoq; the correspondence of the Yakut vocal (o) and Turkic vocal (u): Yakut — moroq Az. — buqag, Turkmen — buqaw, Kumyk — buraq, Bashk. - bŭraq, Kazakh — bŭraq, Uzbek -buqoq; the regular correspondence of the anlaut consonant: $(\mathrm{s} \sim \mathrm{j})$ : Yakut - siäl $\sim$ Proto-Turkic — je: l, old Turk. — jel, Kar.Uyghur — je: 1, Sar. Uyghur — jelä, Turk. — yele, Turk. dial. — yeli; basic correspondence of the Yakut diphthong (iä) with vocalism (e) in Ancient Turkic, Turkish, Sorig-Yugur, Tuvan languages: Yakut — siäl old Turk. — jel, Turk. — yele, Turk. dial. — yeli, Tuv. — čel, Sar. Uyghur — jelä.

According to the basic correspondences of the Turkic consonants, in the Yakut lexical unit siäl in relation to the Proto-Turkic form je: $\mathbf{I}$, there is observed correspondence of the Yakut diphthong (iä) and the Proto-Turkic long vocal element (e:). In Turkish yele means "horse's mane", in Turk. dial. — yeli "horse's mane" and Western Yugur — jelä "horse's mane"; in relation to the Yakut form we can note the presence of the final vocal (i), (ä), (e). In the northeastern Turkic languages, there are two different roots with different semantic meanings: jel and ja: $\mathbf{l}$. The lexical unit ja: $\mathbf{I}$ gets the meaning "mane" in a compact central area, apparently due to contamination with je: $\mathbf{l}(\mathbf{a})$; and its original meaning may be "withers" or, more narrowly, "the horse's fat under mane". In contrast to the Yakut language, in Middle Uyghur, Khorezmian Turkish, Turkish, Turkmen, Altai, Khakass languages there is the preservation of the Proto-Turkic form with the structural type CVCCVC.

\section{Conclusion}

In the course of the research according to lexicographic sources there were identified 12 Yakut names, denoting the names of animals body parts and having lexical reflexes in other Turkic languages. Lexical parallels were examined within the framework of three lexical and semantic groups: 1. External structure, including; 1.1) Head, neck; 1.2) Corpus; 1.3) Limbs (outgrowths) and their types; 1.4) Skin coverings and their types; 2. Internal structure; 3 . Internal body parts and their types. The distribution of lexical 
parallels in terms of structural features is represented as follows: monosyllabic -5 stems (tü:, muos, suy, sa: l, siäl) $-35.7 \%$; disyllabic -6 stems (tujaq, iiraaq, silin, kïnat, tumus, moroq) $-57.1 \%$; trisyllabic -1 stem (kuturuk) $-7 \%$. The percentage indicates that the disyllabic stems have a more stable structural type (in $83 \%$ of disyllabic structures the structural type of CVCVC is observed). The second position is occupied by monosyllabic stems, the last one - by a trisyllabic stem.

Summarizing the analysis of the comparison of the Yakut vocabulary of animal names, one can see how the lexical and thematic group changes from the Proto-Turkic language to the Yakut language, as well as from the Yakut forms to the modern Turkic languages. It has been found that the material of the Yakut language is of decisive importance for the Proto-Turkic reconstruction in terms of many parameters. This version finds its confirmation of the preservation of the Proto-Turkic long vowels in Yakut in the following example: Yakut - tü: // Proto-Turkic — tü: k, Yakut - sa: I // Proto-Turkic ja: I. Phonological analysis of lexical parallels revealed that in many respects the vocabulary of the animal's names in the Chuvash language is in the most remote position from the Yakut language in comparison with other Turkic languages.

\section{References}

Böhtlingk, O.N. (1989). O iazyke iakutov [On the Yakut language]. Novosibirsk.

Levin, G.G. (2013). Istoricheskoe otnoshenie iakutskogo iazyka s drevnetiurkskimi iazykami VII-IX vv. (v sravnitel'no-sopostavitel'nom aspekte s vostochno-tiurkskimi $i$ mongol'skimi iazykami) [Historical relation of the Yakut language to the ancient Turkic languages of the $7^{\text {th }}$ - $9^{\text {th }}$ centuries (in a comparison with the East Turkic and Mongolian languages)]. Yakutsk: Publishing house of the NEFU.

Shaikhulov, A.G. (2000). Struktura $i$ ideograficheskaia paradigmatika odnoslozhnykh kornevykh osnov $v$ kypchakskikh iazykakh Uralo-Povolzh'ia v kontinuume areal'noi, mezhtiurkskoi i obshchetiurkskoj leksiki. Chast' VII [Structure and ideographic paradigmatics of monosyllabic root stems in the Kypchak languages of the Ural-Volga region in the continuum of areal, inter-Turkic and general Turkic lexicon. Part VII]. Ufa: Publishing House of Bashkir University.

Shirobokova, N.N. (2005). Otnoshenie iakutskogo iazyka k tiurkskim iazykam Iuzhnoj Sibiri [Relation of the Yakut language to the Turkic languages of Southern Siberia]. Novosibirsk: Nauka.

Starostin, S.A. (1991). Altaiskaia problema i proiskhozhdenie iaponskogo iazyka [The Altai problematics and the origin of the Japanese language]. Moscow. 
Tenishev, E.R., Blagova, G.F., Dobromov, I.G., Dybo, A.V., Kormushin, I.V., Levitskaia, L.S., Mudrak, O.A., Musaev, K.M. (2001). Sravnitel'no-istoricheskaia grammatika tiurkskih iazykov: Leksika [Comparative and historical grammar of the Turkic languages: Lexics]. Moscow, Nauka, 822 p.

Ubriatova, E.I. (1960). Iakutskii iazyk vego otnoshenii k drugim tiurkskim iazykam, a takzhe k iazykam mongol'skim i tunguso-man'chzhurskim [The Yakut language in its relation to other Turkic languages, as well as to the Mongolian and Tungus languages]. Moscow, Izd-vo Vost.

\title{
Якутская лексика общих названий частей тела животных в сравнительно-историческом аспекте
}

\author{
Н. В. Малышева, А. Е. Божедонова, А. П. Васильева \\ Северо-Восточный федеральный университет \\ им. М. К. Аммосова \\ Россия, 677000, Якутск, ул. Белинского, 58
}

\begin{abstract}
Исторический этап развития тюркских языков, их взаимосвязь с языками монгольской, тунгусо-маньчжурской группь языков и с другими неродственными языками, история переселения тюркских народов и их языковые контакты с другими народами и племенами до сих пор вызывают большой научныий интерес каку этнографов, историков, так и у лингвистов. Лексика общих названий животного мира в тюркских языках представляется одним из наиболее интересных пластов словарного состава, отличающихся древностью, многообразием и самобытностью лексических единиц. В настоящей статье рассматриваются общие названия частей тела животных в рамках трех лексико-семантических групп (далее - ЛСГ): 1. Внешнее строение, в том числе 1.1) голова, шея; 1.2) туловище; 1.3) конечности (выросты) и их виды; 1.4) покров и его виды. 2. Внутреннее строение. 3. Внутренние органы и их виды. Выявляются лексико-семантические, фоноструктурные особенности 12 якутских основ, имеющих лексические параллели в других тюркских языках, а также их семантические переходы. В статье предпринимается попытка определения отношения якутского языка к другим современным тюркским языкам, а также прослеживаются изменения лексических значений рассматриваемых основ от пратюркской формы к современным. В работе устанавливается, что по многим параметрам материал якутского языка имеет решающее значение для пратюркской реконструкиии.

Ключевые слова: зоологическая лексика, современные тюркские языки, пратюркская форма, лексические параллели, фоноструктура, фонологическая особенность, лексикосемантическая особенность, история языка.
\end{abstract}

Исследование выполнено в рамках научно-исследовательского проекта «Героические эпосы тюрко-монгольских народов Евразии: проблемы и перспективы сравнительного изучения».

Научная специальность: 24.00.00 - культурология. 